\title{
Meta
}

Journal des traducteurs

Translators' Journal

\section{DE BENI, Matteo, ed. (2016): Ciencias y traducción en el mundo hispánico. Mantova: Universitas Studiorum, 393 p.}

\section{John Humbley}

Volume 62, numéro 3, décembre 2017

URI : https://id.erudit.org/iderudit/1043958ar

DOI : https://doi.org/10.7202/1043958ar

Aller au sommaire du numéro

Éditeur(s)

Les Presses de l’Université de Montréal

ISSN

0026-0452 (imprimé)

1492-1421 (numérique)

Découvrir la revue

Citer ce compte rendu

Humbley, J. (2017). Compte rendu de [DE BENI, Matteo, ed. (2016): Ciencias y traducción en el mundo hispánico. Mantova: Universitas Studiorum, 393 p.] Meta, 62(3), 653-655. https://doi.org/10.7202/1043958ar

Ce document est protégé par la loi sur le droit d'auteur. L'utilisation des services d'Érudit (y compris la reproduction) est assujettie à sa politique d'utilisation que vous pouvez consulter en ligne.

https://apropos.erudit.org/fr/usagers/politique-dutilisation/
Cet article est diffusé et préservé par Érudit.

Érudit est un consortium interuniversitaire sans but lucratif composé de l’Université de Montréal, l'Université Laval et l'Université du Québec à Montréal. Il a pour mission la promotion et la valorisation de la recherche. https://www.erudit.org/fr/ 
celui d'Enríquez Aranda et Mendoza García sur la documentation dans les programmes de formation de traducteurs ou celui consacré à la conception d'un modèle didactique mixte qui cherche à combiner l'enseignement présentiel avec l'apprentissage en ligne au moyen des TIC dont nous disposons aujourd'hui. La deuxième partie aborde des aspects transversaux de la traduction, dont la thématique des normes linguistiques et la ponctuation (Sánchez-Iglesias), et celle de l'aspect des notes du traducteur (Vega Cernuda et Serrano Bertos).

Translating culture - Traduire la Culture Traducir la Cultura constitue ainsi un ouvrage volumineux et diversifié qui contient un vaste éventail d'articles centrés sur la communication interlinguistique en espagnol, anglais, français, chinois, russe, portugais et italien. Il est sans nul doute un outil essentiel pour tous les chercheurs et professionnels qui travaillent avec ces langues et ces cadres culturels.

Alicia López Tárraga Université de Montréal, Montréal, Canada

De Beni, Matteo, ed. (2016): Ciencias y traducción en el mundo hispánico. Mantova: Universitas Studiorum, 393 p.

In recent years there has been a renewed interest in the history of scientific translation, in particular the role it played in science itself and more broadly in society. These studies generally go from the Renaissance on, as evidenced by the works of Joëlle Ducos (2012) and Pascal Duris (2008), indicative of the many initiatives undertaken in France. With this collection, edited by Matteo De Beni, the Iberian Peninsula is put on the map. It should be noted that this is a companion volume to one on the related theme of the emergence of nomenclatures (De Beni (ed.) 2015). The American historian Peter Dear, quoted by one of the authors of this volume, claims that the role of Hispanic scholars to the scientific revolution, which began in $17^{\text {th }}$ century Europe, has been seriously underestimated. It is to the credit of this volume to attempt - successfully as will be shown - to rectify this situation, bringing to light evidence of scientific exchange through translation, either from the Hispanic languages or into them. The time span here is broad: from the $14^{\text {th }}$ century through the Enlightenment and the $19^{\text {th }}$ century up to the present day. Translation is also interpreted broadly to include lexicography and terminology, sometimes to the exclusion of translation proper.

The publication is divided into five sections. The first, entitled scientific knowledge and heritage bibliography, deals not only with issues of conservation and access but also with the social and scientific dissemination of documents in general, not simply with translation. The first text, by Paola Calef, «Las cosas aromáticas que son para el corazón». La ricetta medica del codice dantesco di Santillana, is a good example of interpenetrating cultural worlds in Italy, Spain and France in both literature and medicine. The study focuses one of several curious additions to the manuscript of the first Spanish version of Dante's Divine Comedy, in the form of the translation of a portion of a medical treatise by the well-known French physician Bernard de Gordon. To uncover the identity of this text, the author surveys the multiple versions, both translations and modifications, that this and comparable medical texts went through up to the $17^{\text {th }}$ century. The second chapter, by Alejandra Ulla Lorenzo, "Iberian Book Project» (1450-1650): sobre los usos del catálogo en el estudio del libro científico antiguo, is purely bibliographical in nature and outlines the project mentioned in the title, which aims to catalogue all books published in Spanishspeaking countries or in Spanish between 1472 and 1650 , as well as other similar initiatives: it appears from these inventories that translations account for $13 \%$ of all scientific texts published in the $15^{\text {th }}$ and $16^{\text {th }}$ centuries, most having a Greek or Latin original. Luis Pablo Núñez, in Tradición y traducción de los textos botánicos: mapa geográfico y cronológico de las obras botánicas en Europa. El caso de la difusión y recepción del Tractado de las drogas (1578) de Cristóbal de Acosta, presents several Spanish and Portuguese books on Asian plants and documents their numerous translations into both Latin and the main Western languages. This introduction sets the stage for the analysis of Acosta's book mentioned in the title, a richly illustrated description of 69 plants found in India. The work was translated into Latin and other modern European languages, which are examined in some detail in the form of a textual history. It transpires that the French translation provides the first attestation of some important natural history terms, such as betel, caïman, tamarin... This article also deals with the migration to the web of these texts, with suggestions on how to improve their accessibility and navigability. The national French heritage document site, Gallica, is cited as exemplary in this line.

The second section concerns lexicon and terminology in translation up to the $18^{\text {th }}$ century, and the first contribution in this part, by Teresa Gil García, Tecnicismos en los primeros vocabularios bilingües español-italiano (siglos XVI y XVII), opens with the claim of a direct relationship between language and scholarship, that the advances of science are not just mirrored but indeed shaped by the language used, though the increasing use of the national languages at the expense of Latin was at the same time undermining the universal 
reach of scientific writing. To a great extent the slack was taken up by translation, which also played a role in making scientific knowledge more broadly accessible to national populations. The dictionaries referred to in the title are general in scope, published at an interval of some fifty years, so the presence of botanical terms can give some limited idea of the scientific development of the Spanish language, though to the extent that most of the plants listed are common ones, there is little need for recourse to what would become standardized nomenclatures. It is shown that these bilingual dictionaries rely heavily on their monolingual counterparts, though without necessarily excluding practical words, as certain official dictionaries tended to do. Oreste Trabucco, in Filologia e ittionimia: il 'Nomenclator aquatilium animantium' di Gesner turns to fish and their definition and equivalences in bilingual dictionaries, compared to the entries in the extraordinary Gesner natural history encyclopaedia of 1555 . He shows how long it took for $17^{\text {th }}$ century bilingual lexicography in several language communities to catch up with the illustrated entries of the previous century's Latin-based encyclopaedism. What use is it, for example, for a non-native speaker to read that a headword is a pesce noto ('well-known fish')? Elisabetta Paltrinieri investigates how names of new foodstuffs from the Americas were integrated into various other European languages, having been sourced from Nahuatl words and summarily adapted into Spanish. In Del cacao a los chiles: equivaliencias y reequivalencias europeas de productos mexicanos a través del primer tratado europeo sobre la naturaleza y calidad del chocolate, she examines the English, French and Italian translations of a 1631 treatise on the benefits of chocolate and how it is prepared. Unsurprisingly, most of the realia were passed into the other three European languages as direct loans, though not without modifications or misinterpretations. Antoni Nomdedeu Rull's contribution is part of an overarching project for a historical scientific and technical dictionary of Spanish. In Botánica y lexicografía en el siglo XVIII: diccionarios tournefortianos y diccionarios linneanos he examines two botanical dictionaries, one from 1762, based on Tournefort's classification by successive division, the other from 1798, based on the principles of Linnaeus and compared with a corpus of $18^{\text {th }}$ century Spanish botanical writing. The earlier of the two dictionaries turns out to be quite militantly anti-Linnaean, perhaps even more stridently so than contemporary French writings. This chapter is a classical study of how dictionaries can be polemical instruments.

The third section of the book, on how scientific texts move to and from the Hispanic world in translated form, is introduced by the editor's presentation of the principles underlying the Proyecto "Traducción y circulación internacional de los textos técnico-científicos hispánicos.” De Beni explains and justifies the large time span of this project, from the time of the discovery of the New World to the first decades of the $20^{\text {th }}$ century, and the inclusion of translations from Spanish into the main Western European languages in a wide range of sciences in book form and periodicals. The methodology is given in some detail, notably the discourse and lexical analysis, underlining the importance of extratextual elements. Elena Dal Maso and Elisa Sartor, in La circulación del saber científico en la Europa del siglo XVIII. Consideraciones textuales y terminológicas acerca de la Dissertacion physico-botanica sobre la passion nephritica de M. Quer (1763) y su traducción el francés (1768), analyze the translation of a short work of the Spanish botanist who features in Nomdedeu's article as another ardent Tournefort supporter, a position he by no means abandons in this other work. The authors conclude that the French translator was an expert in both medicine and botany, as he takes what appear to be perfectly justifiable liberties, even at times correcting the original. The study is enriched by references to the botanical terms present in a wide range of dictionaries of the period. Natividad Gallardo San Salvador and Carmen Navarro in El papel de la traducción en la difusión de los saberes científicos en el siglo XVIII español, focus on translations into Spanish of scientific texts from the time of the Spanish Enlightenment until the $19^{\text {th }}$ century in a wide variety of fields. The reader may well be surprised at how long it took the Catholic church to waive objections to Copernican theory even in translation, and impressed with how rapidly the revolutionary eighteenth century texts in chemistry and botany were rendered into Spanish. As may be gathered from these two disciplines, the adaptation of terminology is a major issue, dealt with in some depth in this chapter. A rich field indeed! Julia Pinilla Martínez shifts the focus to the $19^{\text {th }}$ century and to the translation of school text books. In Ciencias naturales, enseñanza y traducción, the author examines the three translations into Spanish of a French natural history text, which itself went through two successive editions, against the backdrop of political instability in Spain and the repercussions on educational policy (the role of the Church is again highlighted). Themes investigated include the widely differing translation stance by the three translators, the role of terminological adaptation, as well as a passing mention to financial conditions of translating.

This chapter forms a transition to the fourth part, devoted to translation in relation to popular 
science and education of the present day, which includes two essays: one by Maria Amalia Barchiesi, Apuntes para una semiótica de los textos cientificos divulgativos en lengua española, the other by Marco Paone and Lorena Paz López, Ciencia, ironía y traducción: Tiempo de silencio de Luis Martín-Santos. The first analyzes contemporary Spanish texts on ecology, focusing on the threatened Mexican oak tree producing the world's largest acorn. The analysis is taken from a semiotic point of view, drawing on such authorities as the semioticians Greimas, Jacobi and Latour and the work of those involved in popularizing science, the techniques used being presented as a form of translation: a fresh look at a well-known theme. The second is a study of the translation of scientific terms from a 1960s Spanish novel translated into French and Italian, an example of 'professional substratum fiction' ${ }^{1}$ much studied in France. This chapter is well illustrated with contrasting examples of translating strategies:

The final section focuses on image in scientific translation and consists of the texts by Francesc Rodríguez and Cecilio Garriga, Ilustraciones de la ciencia en la lexicografía española, and Peter Mason's El rol de las Canarias en la traducción visual del Nuevo Mundo para el Viejo Continente. The first is a very complete account (within the scope of a single chapter) of the role of illustrations in monolingual dictionaries and an in-depth study of those in the Spanish adaptation of the ground-breaking Petit Larousse illustré, in the early part of the twentieth century, appropriately profusely illustrated. The second chapter traces the many illustrations of the miraculous water-bearing garoé tree on the Canary Islands in Girolamo Benzoni's 1565 description (featuring in a book on the Americas, thus the title), its re-editions and many translations and the reinterpretations they both embodied and prompted.

As the editor rightly points out, the history of scientific translation is by definition an interdisciplinary endeavour. Not all of the contributors are primarily researchers in translation studies, which can lead to a wish for more depth in translation analysis. For example, in several texts the relations between translation and equivalence are hinted at rather than made explicit: to what extent did the translator have recourse to a pre-existing term in the target language, or did this new term have to be coined by the translator? But works such as these open up a dialogue where such issues can be investigated.

Translation specialists as well as those with an interest in the history of science and ideas will find this a rich repository.

\section{NOTE}

1. For more information on 'FASP,' see Petit, Michel and IsanI, Shaeda, eds. (2004): Aspects de la fiction à substrat professionnel. Bordeaux: Université Victor Segalen.

\section{REFERENCES}

De Beni, Matteo, ed. (2015 ): De los descubrimientos a las taxonomías. La botánica y la zoología en la lengua española del Renacimiento a la Ilustración. Mantova: Universitas Studiorum.

Ducos, Joëlle, ed. (2011): Sciences et langues au Moyen-Âge. Heidelberg: Winter.

Duris, Pascal, ed. (2008): Traduire la science. Hier et aujourd'hui. Pessac: Publications de la Maison des sciences de l'homme d'Aquitaine.

Alonso Araguás, Icíar, PÁez Rodríguez, Alba y Samaniego Sastre, Mario, eds. (2015): Traducción y representaciones del conflicto desde España y América. Una perspectiva interdisciplinar. Salamanca/Temuco: Ediciones Universidad de Salamanca/Universidad Católica de Temuco, $257 \mathrm{p}$.

Si la traducción ha sido frecuentemente conceptualizada en relación con el conflicto (y eso desde mucho antes de la formación de nuestra disciplina, por ejemplo, en Steiner 1975), el interés por su papel mediador está íntimamente vinculado con el surgimiento del traductor como objeto de estudio, a partir del Cultural Turn. La presente obra constituye un aporte significativo a ambos temas, proponiendo unas miradas cruzadas (provenientes de España y de América) sobre el conflicto $y$, ante todo, sobre su mediación intercultural e interlingüística.

Publicado por las Ediciones de la Universidad de Salamanca y por las de la Universidad Católica de Temuco, Traducción y representaciones del conflicto desde España y América. Una perspectiva interdisciplinar ha sido coeditado por Icíar Alonso Araguás, Alba Páez Rodríguez y Mario Samaniego Sastre. Presenta, a través de 14 artículos (incluyendo el último que desempeña la función de epílogo), las reflexiones que surgieron del encuentro Mediación, migraciones e interculturalidad. Perspectivas históricas y contemporáneas desde España y América que tuvo lugar en Salamanca, en febrero 2014. Convocado por la Universidad de Salamanca (USAL), este evento reunió a 3 grupos de investigación (Alfaqueque y GIR Traducción, Ideología y Cultura de la USAL, Frontera de Lenguas de la Universidad Católica de Temuco), así como a investigadores procedentes de varias otras instituciones. Cabe mencionar que la presente obra, también continúa en la línea del encuentro 